https://helda.helsinki.fi

\title{
Creating a Lexico-Semantic Typology of Water-Related Onomatopoeic Interjections (On Russian and Finnish Material)
}

\section{Viimaranta, Johanna}

2020-06-22

Viimaranta , J \& Bogomolov , A 2020 , ' Creating a Lexico-Semantic Typology of Water-Related Onomatopoeic Interjections (On Russian and Finnish Material) ', Vestnik Tomskogo gosudarstvennogo universiteta. Filologiâ , vol. 65 , no. 65 , pp. 5-29 . https://doi.org/10.17223/19986645/

http://hdl.handle.net/10138/317522

https://doi.org/10.17223/19986645/65/1

unspecified

publishedVersion

Downloaded from Helda, University of Helsinki institutional repository.

This is an electronic reprint of the original article.

This reprint may differ from the original in pagination and typographic detail.

Please cite the original version. 


\title{
ЛИНГВИСТИКА
}

УДК $81-23$

DOI: $10.17223 / 19986645 / 65 / 1$

\author{
Й. Виймаранта, А.С. Богомолов
}

\section{ОПЫТ ЛЕКСИКО-СЕМАНТИЧЕСКОЙ ТИПОЛОГИИ «ВОДНЫХ» ЗВУКОПОДРАЖАТЕЛЬНЫХ МЕЖДОМЕТИЙ НА МАТЕРИАЛЕ РУССКОГО И ФИНСКОГО ЯЗЫКОВ}

\begin{abstract}
Рассматриваются значение и употребление в русском и финском языках звукоподражательных междометий, связанных с водой. Представлена типология таких слов с точки зрения тех признаков значения, которые влияют на выбор слова-дескриптора для описания «водной ситуации». Для русского языка типология основывается на данных словарей и интуиции носителя языка, для финского языка - на результатах электронного анкетирования 124 респондентов и интуиции носителя языка.

Ключевые слова: звукоподражание, междометие, типология, русский язык, финский язык.
\end{abstract}

\section{Введение}

Объект нашего исследования - воссоздающие звук или называющие действие формы типа хлоп и хвать, фигурирующие в высказываниях о ситуациях, ключевыми элементами в которых являются предмет и жидкость ${ }^{1}$. В целях упрощения описания речевого материала данные ситуации мы назвали водными ситуациями; звуки, сопровождающие подобные ситуации, - водными звуками; а слова, используемые для репрезентации таких ситуаций, - водными звукоподражательными междометиями. Что касается причастного к некоторой водной ситуации предмета, то им может быть неодушевленный предмет: как объект действия (Достал из морозилки пакет пельменей, открыл и бултых весь их смерзшийся кусок в кипяшую воду), как субъект действия (Только он перегнулся через край лодки, ключи из кармана - бульк в воду), в том числе жидкость (Вода с дерева после дождя то и дело кап да кап) или пузыри (В комнате было тихо, только пузыри 8 аквариуме - буль-буль-буль), а также живое существо: как активный субъект действия (Уборщцца хлесть водой из ведерка на пол) или пассивный его объект (Рыбак толкнул напарника, тот - плюх за борт). Контексты с участием одушевленного предмета (в первую очередь человека), произво-

\footnotetext{
${ }^{1}$ Выделение особой разновидности ситуаций, в которых жидкость - единственный каузатор значимого (актуализированного в отдельной лексеме) водного визуальноакустического эффекта, кажется несостоятельным, поскольку любое водное звучание оказывается явно или неявно детерминировано воздействующим на жидкость предметом. Без такого воздействия жидкость вообще пребывает в состоянии покоя либо незначимого визуально-акустического движения.
} 
дящего в полости рта или с ее помощью некоторые водные или сходные с водными звуки (типа гльды, тьфу, хлесть (в значении пить), хлюn (при насморке, плаче), чавк, чих, чмок (от всасывающего движения губ), имыьг и т.п.), а также индивидуально-авторские образования (Вуш-ш - неожиданно вынырнул из глубины огромный синий кит) не входят в число рассматриваемых в данной работе. Однако разницу между устойчивыми звукоподражательными междометиями (в терминах Rhodes [1] tame «прирученные») и окказиональными образованиями (wild «дикие») [Там же] намного легче определить в русском языке, где подобные слова лучше описаны и их можно найти в словарях, чем в финском, для которого таких описаний нет.

Вопрос о частеречной принадлежности форм типа хлоп и хвать в русском языке не имеет однозначного решения. В зависимости от семантических и синтаксических функций слова этого типа могут относиться к глагольным междометиям и смежным с ними звукоподражательным междометиям [2. § 1700], а также к особым или усеченным отглагольным формам, собственно (нарративным) предикативам или «звуковым жестам», вовсе не имеющим никаких специфических глагольных характеристик и показателей [Там же. $§ 1705 ; 3-5]$. Для целей нашей работы (несмотря на возможную функциональную омонимию, возникающую из синтаксической роли конкретного слова в предложении (см. об этом, например: [6. С. 8791]) достаточной представляется академическая трактовка рассматриваемой группы лексики как глагольных междометий (для слов типа хвать) и звукоподражаний (для слов типа хлоn). В любом случае единая трактовка и звукоподражательных, и глагольных междометий поддерживается тем, что нередко человеку на самом деле трудно различать информацию, полученную разными средствами восприятия, что неоднократно подтверждалось путем психологических экспериментов [7-11].

Подобные слова в финском языке называются либо звукоподражательными междометиями, идеофонами, либо имитативами. Так же, как и в русском языке, среди них существуют междометия глагольного типа (в финской терминологии takaperoisjohdetut, букв. «образованные с конца / наоборот» междометия), которые и по форме и по значению близки к русским глагольным междометиям, т.е. речь идет о неизменяемых словах, в которых имеется только корень без глагольных суффиксов. Вместе с тем в качестве отступления от общего правила в конце звукоподражательного слова можно встретить суффикс -is. Однако он не имеет конкретного значения, а лишь допускает наличие вариантов у конкретного междометия: с этим суффиксом или без него. Существует не так много научной литературы об этих словах в финском языке, основополагающими являются докторские диссертации Э. Миконе [12], где дескриптивная лексика (в том числе звукоподражания) сравнивается с аналогичными словами в эстонском языке, и А. Яяскеляйнен [13], где звукоподражательные междометия финского языка рассматриваются с точки зрения грамматики конструкций. Опираясь на материалы Интернета, форумов и газетного корпуса, Яяскеляйнен намного основательнее, чем кто-либо до нее, обращает наше вни- 
мание на широкие возможности этих слов в финском языке. Однако «водные» звукоподражания не играют особой роли в работе. Зато они были объектом исследования в [14], где с помощью эксперимента типа «licitation test» выяснялось, какими словами и предложениями носители русского и финского языков описывают типичные «водные» ситуации.

Приведенные ранее примеры отражают синтаксическую особенность русских междометий, их способность выступать в функции сказуемого. Такая функция вообще типична только для славянских языков $[15,16]$. Финские звукоподражательные и глагольные междометия обычно не могут в письменной речи заменить глагольные формы, что отражается в том, что в переводах таких предложений на финский язык употребляются, скорее всего, либо комбинации обыкновенного глагола со звукоподражательным междометием, либо звукоподражательные глаголы.

\section{«Водные» звукоподражательные междометия русского языка (по данным словарей)}

Обозначив рамки нашего исследования, можно установить актуальный ${ }^{1}$ для современного (вторая половина XX в. - 2016 г.) русского языка кодифицированный инвентарь водных звукоподражательных междометий. Согласно данным словарей [4, 17-19] современный набор русских водных звукоподражательных междометий составляют слова: бултых, буль и бульк, кап, нырк (нырь), плюх, пшик, хлесть (хлесь), хлюп, чмок и шлеп. Рассмотрим содержание каждого из этих слов по отдельности и попробуем обобщить полученное.

Звукоподражание бултых может использоваться для обозначения звука всплеска жидкости или действия, обусловливающего появление подобного звука или визуально-акустического эффекта. Типичные (закрепленные в лексическом значении слова) водные ситуации, при описании которых употребление слова бултых оказывается уместным, образуют следующие контексты: 1) всплескивание поверхности жидкости (Володя задумчиво сидел на берегу и вдруг бултых ногой по воде); 2) взбалтывание жидкости, заключенной в емкость (Всю дорогу из бочек - бултыхх да бултых ); 3) падение (бросок) предмета в жидкость (Нависающий край льдины неожиданно треснул и бултых в воду. Перебегая по бревенчатым мосткам, Федор поскользнулся и бултых в реку). Вместе с тем последнее возможно, если адресатом действия выступает что-либо мягкое вообще (снег, сено и т.п.), а не только жидкость (Почуяв что-то, лиса замерла, напряженно подобралась и бултых в сугроб) [17. Т. 2. С. 248-249; 18. Т. 1. С. 133; 19. С. 102].

Звукоподражания буль и бульк используются для обозначения характерных водных звуков или действий, сопровождающих или порождающих подобное звучание в некоторых водных ситуациях. Близость контекстов, описываемых схожими словами буль и бульк, часто наводит на осмысление

\footnotetext{
${ }^{1}$ О нестабильности репертуара слов типа хлоп и хвать см.: [3. С. 153-155].
} 
этих звукоподражаний как вариантов друг друга (в словарных статьях одно из них может указываться в скобках либо не упоминаться вовсе), передающих один и тот же смысл. В случае различения данных слов в словарях они получают самостоятельные значения, которые вообще могут поразному и не всегда оправданно сортироваться ${ }^{1}$. Так, в [17] различаются звукоподражания буль и бульк и по-своему распределяются исключительно водные ситуации, эти слова определяющие; наряду с этим в словарях Т.Ф. Ефремовой и С.А. Кузнецова некоторые похожие водные контексты также фиксируются, но связываются они только с одним словом - буль (буль-буль). Не сопоставляя словарные статьи в названных источниках, укажем все отмеченные ими водные ситуации, для описания которых использование звукоподражаний буль и бульк будет адекватным: 1) движение жидкости из источника (узкогорлого) (Вода сбивчиво струилась из кранабуль, буль-буль); 2) кипение, бурление и похожие состояния жидкости (в том числе их имитация) (Погрузив велосипедную камеру в воду, он почти сразу усльшиал тихое буль-буль, а потом разглядел прокол, из которого иелочкой бежали мелкие пузырьки); 3) падение предмета в жидкость (Беглеч сдвинул крышку люка и, чтобы проверить догадку, смахнул внутрь валявшуюся рядом гайку - бульк! раздалось через секунду) [17. Т. 2. С. 249, 251; 18. Т. 1. С. 134; 19. С. 102].

Вслед за авторами Большого академического словаря [17] мы также различаем слова буль и бульк, но хотели бы предложить свою трактовку их соотношения с обусловливающими их контекстами. Во-первых, стоит внимательнее присмотреться к визуально-аккустическим эффектам ситуации бурления, кипения и их аналогов, а также ситуации движения жидкости из узкогорлого источника (например, выливания жидкости из сосуда). Физически во всех этих случаях мы имеем дело с движущимся сквозь толщу жидкости или сформировавшимся в неровном потоке жидкости пузырьком воздуха, который стремится к ее поверхности, чтобы там лопнуть, издав нечто похожее на резкое и односложное «буль». Осмысление последнего момента как состоящего из двух частей (формирование пузырька на поверхности жидкости и его шумное лопанье) на практике часто приводит к описанию этой водной ситуации при помощи склонного к двусложности слова бульк (ср. произношение буль и буль $\left.\left[\kappa^{\ni}\right]\right)$. Подобному осмыслению и выбору бульк в качестве дескриптора ситуации способствует также однократность или отрывистость повторения данного действия. Однако при быстром и многократном повторении движения пузырьков сквозь жидкость (что, по замечаниям словарей, вообще частотно для данного контекста) и попытке репрезентации этой ситуации с помощью одного из возможных вариантов - буль или бульк - артикуляционно более доступным

\footnotetext{
${ }^{1}$ Сказанное, если и не имеет существенного влияния на практику словоупотребления (тем более междометий и звукоподражаний) в рамках относительно свободного разговорного языка, может представлять определенный интерес для целей перевода, лексикографии и лексико-семантической типологии в принципе.
} 
оказывается первый вариант (ср. буль-буль-буль и бульк-бульк-бульк в ситуации кипения-бурления и т.п.). Во-вторых, при восприятии другой ситуации - падение предмета в жидкость - на слух в ней различимы два момента: первый - звук от столкновения предмета с жидкостью и второй - звук от капли / струи жидкости, которая поднялась и упала, будучи вымещенной этим столкновением. По нашему мнению, этот второй добавочный звук закреплен в слове бульк и передается конечным взрывным -к (ср. булmblx при падении крупного предмета в жидкость). В том случае, когда предмет из этого же контекста, погрузившись в жидкость, оставляет после себя лопающийся пузырь (или так этот момент осмысляется), в качестве дескриптора ситуации может употребляться звукоподражание буль.

Таким образом, ввиду разнонаправленности движения субъектов действия (из жидкости или, наоборот, в жидкость), хоть и адресованного в одну и ту же зону (поверхность жидкости), рассматриваемые водные контексты можно назвать лишь смежными и схожими по акустическому качеству порождаемого звука, но не идентичными. При этом физические особенности самого действия в данных водных ситуациях делают процесс с поднимающимся пузырьком воздуха более соотносимым со словом буль (как минимум при многократном повторении процесса), а процесс с падающим предметом - со словом бульк.

В дополнение к данному блоку заметим, что встретившиеся нам во время проработки проблемы настоящей статьи примеры (помимо словарных) позволяют добавить еще одну водную ситуацию, связанную со звукоподражанием бульк, а именно: удар жидкости обо что-либо (Oн встряхнул темную бутыль и усльшиал заветное бульк; Бульк-бульк - мягко бились волны о еле выходивший из воды холмик гладкого камня).

Звукоподражание кап употребляется (часто с повторением) для обозначения водного звука или действия, связанного с такими водными ситуациями, как 1) движение жидкости из источника (Kan-каn - падали на письмо скатывающиеся по ее щекам слезы) или 2) удар жидкости о твердую поверхность (Всю ночь из-за плохо закрытого кухонного крана доносилось

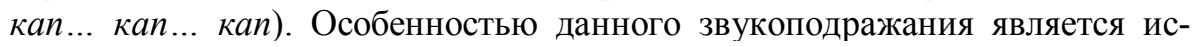
ключительная употребимость его для описания ситуаций, в которых задействована жидкость или жидковатое вещество в виде капель [17. Т. 7. С. $626 ; 18$. Т. 1. С. $643 ; 19$. С. 415$]$.

По данным Большого академического словаря [17], глагольное междометие нырк и его вариант нырь употребляются для обозначения действия по глаголу нырять/-нуть. Хотя в числе первых смыслов этого глагола указываются значения, связанные с водными ситуациями, среди них есть и не имеющие прямой связи с подобными контекстами. Не останавливаясь на последних, сформулируем типичные водные ситуации, для описания которых употребление глагола нырять будет целесообразным: 1) полное погружение в жидкость субъекта действия; 2) движение предмета вверх-вниз по волнам. Поскольку действие во второй ситуации (хоть и водной, но не несущей в своем «чистом» воплощении значимых для нашего анализа ви- 
зуально-акустических эффектов: предмет лишь пассивно следует движениям жидкости, никак не изменяя или детерминируя это движение) есть лишь повторение характера действия первой, будем считать ее - первую ситуацию - единственным водным контекстом, соотносимым с междометием нырк (нырь) [17. Т. 12. С. 635, 637-639].

Останавливаясь подробнее на водной ситуации, характерной для междометия нырк (нырь), нужно заметить, что само действие в ней может быть произвольным, т.е. контролироваться субъектом действия (живым существом), находящимся на поверхности жидкости (Утка разглядела что-то в глубине и нырк (нырь) под / в воду) или вообще не находящимся в ней изначально (Усевшись на борт лодки, он еще раз поправил маску и нырк (нырь) в воду), а также - непроизвольным, т.е. не контролироваться субъектом действия (неодушевленным предметом), изначально частично находящимся в жидкости (Только закинешь удочку и дождешься, когда разойдутся круги на воде, поплавок нырь (нырк) под воду-тащи, не зевай). Что касается осмысления вариантов нырк и нырь как разных междометий - на что может навести форма этих слов по аналогии с различением звукоподражаний буль и бульк (см. выше), то единственность водной ситуации, с ними соотносимой, и сам ее характер не дают оснований для развития подобной мысли.

Звукоподражание плюх может использоваться для обозначения звука удара или действия, завершившегося таким ударом. Типичными водными ситуациями, для описания которых может быть использовано звукоподражание плюх, являются: 1) вызвавший всплеск жидкости удар (падение) часто плашмя предмета о (в) жидкость (Нередкий финал погони в кино - машина срывается с берега и плюх в воду); 2) удар(ы) жидкости обо что-либо (Плюх... плюх... плюх - мягко бились о гранитные ступени длинные волны). В дополнение к первой ситуации надо сказать, что адресатом действия в ней может быть не только жидкость (Витюша так долго кружился, что, остановившись, не удержался на ногах и плюх на пол; Водитель рывком приподнялся и, схватив документы, плюх назад в кресло; Продавщиица отрезала кусок мяса и плюх его на весы) [Там же. Т. 17. С. 120-121; 18. Т. 2. С. $120 ; 19$. С. 846].

Звукоподражание пиик употребляется для обозначения как звука, так и действия в ситуациях, сопровождающихся шипением вырвавшейся струи воздуха, газа, жидкости и т.п. Констатируя из этого наличие собственно водной ситуации, соотносимой со звукоподражанием пшик (движение жидкости из источника), необходимо также указать важную ее особенность: состояние жидкости в струе, вырвавшейся с шипением, должно быть только похоже на газообразное (этому соответствует рассеивание жидкости), но не являться таковым (Напоследок она схватила со столика духи - пиик-пиик - и, бросив флакончик на кресло, выбежала из комна$m b l$ ). В противном случае данная ситуация не может относиться к водной, а следовательно, будет выходить за рамки нашего внимания (Пии-u-к-раздалось в мастерской, когда Данила сунул раскаленный гвоздь в бочонок $c$ 
водой. Если считать, что источником звука в данной ситуации является жидкость, то перед нами реализация типичной водной ситуации, связанной со словом пшик; если пар - перед нами иная, неводная ситуация) [17. Т. 21. C. 581-582; 18. T. 2. С. 411; 19. С. 1051].

Глагольное междометие хлесть (хлесь), по данным словаря С.А. Кузнецова, употребляется для обозначения действия или удара как результата это-

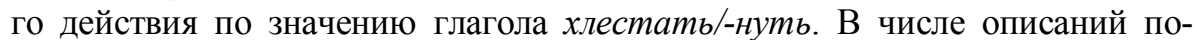
следнего есть и толкования, связанные с водными контекстами: 1) бить, идти, фонтанировать сильной струей и т.п.; 2) лить, плескать жидкость. Исходя из этих глагольных значений, можно сформулировать следующие соотносимые с междометием хлесть (хлесь) водные ситуации: 1) движение жидкости из источника (Вода напоследок хлесь-хлесь мутной струей из крана и больше не показывалась); 2) удар жидкости обо что-либо (Один из собеседников не выдержал и хлесть оппонента водой из стакана; Жирные струи фонтана подлетят, чуть замрут на высоте $u$ - хлесть - почти разом опадут назад) [18. Т. 2. С. 937; 19. С. 1445]. Несмотря на фонетический состав междометий хлесть и хлесь, а также количество ситуаций, соотносимых с этими словами, подобрать веские основания для понимания их как разных слов вообще или различных лишь в оттенках значений довольно трудно.

Звукоподражание хлюn употребляется (часто с повторением) для обозначения хлюпающего, чавкающего водного звука либо хлюпания как действия. Исходя из словарного значения слова хлюп, водными ситуациями, соотносимыми с этим звукоподражанием, оказываются следующие: 1) чавкающий всплеск жижи, грязи, иной жидкой массы или жидкости, подвергнутой воздействию какого-либо предмета (Снег подтаял, и под окнами, выходящими на тротуар, то и дело сльшиалось торопливое хлюп, хлюп, xлюn); 2) чавкающий всплеск жижи, грязи, иной жидкой массы или жидкости, вызванный ее столкновением с чем-либо (Плеснешь в бетономешалку водbl, и раствор сразу - хлюп, хлюп, хлюn); 3) вязкое тягучее бурление жижи, грязи, иной жидкой массы или жидкости (Хлюп... хлюn - медленно булькало варенье на плите). Составляющая одно из значений слова хлюп ситуация звучания или порождения человеком всхлипывающих звуков (при насморке, плаче) ввиду обговоренных выше условий нашего исследования здесь не рассматривается [18. Т. 2. С. 939; 19. С. 1446].

Звукоподражание чмок употребляется для обозначения звука, производимого всасывающим движением губ, а также поцелуя или другого действия вызывающего или сопровождающего чмокающее звучание. Эти «другие» действия, вызывающие или сопровождающие чмокающее звучание, можно связать и с водными ситуациями. Назовем эти ситуации: 1) чавкающий всплеск жидкости или жидковатой массы как результат воздействия на нее предмета (Дерево накренилось, хрустнуло и чмок в боло$m o) ; 2)$ чавкающий всплеск жидкости или жидковатой массы, вызванный ее столкновением с чем-либо (Чмок, чмок, чмок - ритмично целовали небольшие волны днище кормы парусной красавицыь «Фазиси»); 3) высвобождение предмета из жижи, грязи, иной вязкой жидкой массы или жидкости 
(Чмок, чмок - с трудом выдернул он свои сапоги, увязнув в трясине; Каждый раз, когда сосед поднимал стакан из мокрого блюдияа, раздавалось чуть сльишное чмок) [18. Т. 2. С. 991; 19. С. 1482-1483].

Звукоподражание илеп употребляется для обозначения звука шлепка или действия, сопровождающегося таким звуком. В словарном описании звукоподражания шлеп встречаются значения, позволяющие сформулировать собственно водные ситуации, для описания которых употребление слова шлеп будет целесообразным. К ним относятся: 1) удар (падение) чаще плоского предмета о (в) жидкость (Мячик перелетел через забор и шлеп в воду. Шлеп-шлеп-шлеп - зашумели плиць водного колеса); 2) удар жидкости обо что-либо (Одна за другой волнь набегают и шлеп о причальную стенку). Кроме водных, данное звукоподражание часто соотносится и с иными контекстами (Павлик бросил снежок - илеп! - прямо в окно) [18. Т. 2. С. $1020 ; 19$. С. 1501].

Итак, просмотрев выделенные для данных звукоподражаний и междометий водные ситуации, можно сделать некоторые классифицирующие обобщения и назвать следующие прототипы водных ситуаций: 1) передающих идею воздействия предмета как субъекта или объекта действия на жидкость, являющуюся конечным адресатом действия (тип а); 2) передающих идею выхода из жидкости предмета, изначально находящегося в ней (тип b); 3) передающих идею взаимодействия жидкости как субъекта действия и предмета (преграды или поверхности) как адресата действия (тип с); 4) передающих идею движения жидкости из предмета (источника) (тип d). Во всех названных типах водных ситуаций взаимодействие предмета и жидкости сопровождается значимым визуально и/или акустическим изменением исходного состояния последней, которое в зависимости от его конкретных особенностей может быть передано одним или несколькими имеющимися в языке водными звукоподражаниями или междометиями. Здесь нужно понимать, что по своим характеристикам (на глаз и/или на слух) каждый новый случай взаимодействия жидкости и предмета вообще неповторим и может быть только похож на любое другое, даже аналогичное по своей типологической идее взаимодействие. В этой связи, если степень сходности реализации однотипных водных ситуаций ощутимо мала, это и обусловливает появление в языке нескольких подходящих для описания таких ситуаций слов. При этом отличия оттенков в значениях используемых синонимов-дескрипторов призваны отражать видимые и/или слышимые отличия реализации аналогичных по своей идее ситуаций (см., например, наличие бултых, бульк, плюх, хлюп, чмок, илеп и нырк (нырь) для ситуаций типа (a)). Проанализировав особенности ситуаций и оттенки значений их возможных дескрипторов, можно вывести критерии водных ситуаций для каждого из выделенных типов.

На наш взгляд, для водных ситуаций типа (a) и (b) критериями их внутритипового различения будут: 1) визуально-акустическое качество взаимодействия предмета и жидкости (большое, среднее или минимальное количество брызг; особенности сопутствующего звучания); 2) итог взаимодей- 
ствия (степень контакта предмета с жидкостью); 3) характеристики предмета (крупный или маленький; его форма, конкретная разновидность) ${ }^{1}$. В ситуациях типа (c) помимо критериев выделяются два вида: столкновение жидкости с преградой (критерии: 1) акустическое качество столкновения жидкости с преградой; 2) характеристика самой преграды) и падение жидкости на твердую поверхность (критерии: 1) особенность формы жидкости; 2) визуально-акустическое качество столкновения с поверхностью). И наконец, для водных ситуаций типа (d) можно выделить: 1) критерий акустического качества взаимодействия источника и жидкости; 2) особенность формы выходящей из источника жидкости.

Что касается слов нырк (нырь) и хлесть (хлесь), то идеи их значения (см. выше) допускают их включение в группу водных ситуаций типа (а) и $(\mathrm{c}, \mathrm{d})$ соответственно. Однако наряду с этим статус этих слов как глагольных междометий, передающих процесс, а не его качества, в достаточной степени ограничивает их трактовку в рамках системы критериев водных звукоподражаний.

Перенесем наши наблюдения в таблицы типов водных ситуаций и соответствующих им звукоподражательных междометий (табл. 1-4).

Итак, мы рассмотрели современный кодифицированный состав русских водных звукоподражательных междометий, а также набор типичных водных ситуаций, с ними связанных. Очевидно, это лишь часть ситуаций, с которыми сталкивается человек, хорошо знакомый с водной средой и ее свойствами, а звукоподражательные междометия - лишь один из способов эти ситуации описать (см. например, такие контексты и их дескрипторы: вода журчит, испаряется, струится - глагол; прилив, отлив, прибой, водопад - существительное; вода воронкой ушла в трубу - описательная форма и др.).

\footnotetext{
${ }^{1}$ Представляется сложным точно определить то, когда водной ситуации присуще большое, когда среднее, а когда минимальное количество брызг, а также то, в каком случае один предмет, взаимодействующий с жидкостью, считать крупным, а в каком маленьким. С одной стороны, выбор качества характеристики водной ситуации зависит от субъективного осмысления ее говорящим. С другой - нельзя не заметить, что однотипные водные ситуации могут вполне объективно отличаться (ср. количество брызг от глыбы айсберга, упавшего в воду, или от куска сахара, упавшего в кружку с чаем; см. также наличие критериев оценки результата в соревнованиях по прыжкам в воду). В этой связи, чтобы количество брызг в водной ситуации можно было использовать как параметр их различения, следует, допуская некоторую погрешность от упрощения, ориентироваться на принцип взаимоисключения: если брызг в ситуации не большое и не минимальное количество, то их - среднее количество и т.д. Что касается размера предмета, задействованного в водной ситуации, то маленьким можно считать предмет, который при взаимодействии с жидкостью дает минимальное количество брызг. Как показывает практика, такой предмет имеет максимальный размер немногим больше крупной дождевой капли, либо он имеет обтекаемую форму, что в поперечном сечении (важно при вертикальном падении) покажет такой же размер. Крупными же можно назвать все остальные предметы, которые при взаимодействии с жидкостью дадут более чем минимальное количество брызг.
} 
Т а бл и ц а 1

Тип (а): ПРЕДМЕТ $\downarrow$ ЖИДКОСТЬ (в жидкость, на жидкость, по жидкости) $=$ ВСПЛЕСК, БРЫЗГИ И/ИЛИ ВОДНЫЙ ЗВУК

\begin{tabular}{|c|c|c|c|c|c|}
\hline \multicolumn{2}{|c|}{ Дескриптор } & $\begin{array}{c}\text { Качество } \\
\text { столкновения }\end{array}$ & \begin{tabular}{|c|} 
Итог столк- \\
новения
\end{tabular} & Предмет & Примечание \\
\hline \multicolumn{6}{|c|}{ субъект $(\rightarrow$ объект) $\downarrow$ жидкость } \\
\hline бултых & $\begin{array}{l}\text { «в воду» } \\
\text { «По воде» }\end{array}$ & $\begin{array}{l}\text { Большое коли- } \\
\text { чество брызг, } \\
\text { наличие звука } \\
\text { бултыханья }\end{array}$ & $\begin{array}{l}\text { Полное или } \\
\text { почти пол- } \\
\text { ное погру- } \\
\text { жение } \\
\text { предмета } \\
\end{array}$ & $\begin{array}{l}\text { Крупный } \\
\text { и/или тяже- } \\
\text { лый }\end{array}$ & $\begin{array}{l}\text { Адресатом действия } \\
\text { преимущественно } \\
\text { является жидкость, } \\
\text { но может быть что- } \\
\text { либо мягкое вообще }\end{array}$ \\
\hline бульк & «в воду» & \begin{tabular}{|l|} 
Минимальное \\
количество \\
брызг, наличие \\
звука, похожего \\
на однократное \\
бульканье; воз- \\
можно образова- \\
ние лопающегося \\
пузырька воздуха \\
на поверхности \\
жидкости \\
\end{tabular} & $\begin{array}{l}\text { Полное } \\
\text { погружение } \\
\text { предмета }\end{array}$ & $\begin{array}{l}\text { Маленький } \\
\text { или обтека- } \\
\text { емый, мо- } \\
\text { жет быть } \\
\text { капля }\end{array}$ & 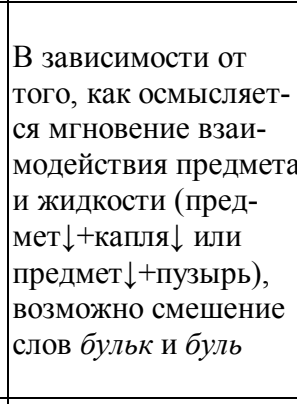 \\
\hline \multirow[t]{2}{*}{ плюх } & |«в воду» & \begin{tabular}{|l|} 
Большое или \\
среднее количе- \\
ство брызг, \\
наличие звука, \\
похожего на \\
шлепок \\
\end{tabular} & $\begin{array}{l}\text { Частичное } \\
\text { или полное } \\
\text { погружение }\end{array}$ & $\begin{array}{l}\text { Часто } \\
\text { упавший } \\
\text { плашмя }\end{array}$ & \multirow{2}{*}{$\begin{array}{l}\text { Обычно адресатом } \\
\text { действия является } \\
\text { жидкость }\end{array}$} \\
\hline & $\begin{array}{l}\text { «на воду» } \\
\text { «по воде» } \\
\text { иногда с } \\
\text { повторени- } \\
\text { ем }\end{array}$ & То же самое & $\begin{array}{l}\text { Контакт, без } \\
\text { погружения }\end{array}$ & То же самое & \\
\hline \multirow[t]{2}{*}{ хлюп } & $\begin{array}{l}\text { «в грязь/-и» } \\
\text { «в воду/-е»» }\end{array}$ & \begin{tabular}{|l|} 
Среднее или \\
минимальное \\
количество \\
брызг; наличие \\
звука хлюпанья \\
\end{tabular} & $\begin{array}{l}\text { Частичное } \\
\text { или полное } \\
\text { погружение }\end{array}$ & $\begin{array}{l}\text { Крупный } \\
\text { и/или тяже- } \\
\text { лый }\end{array}$ & \multirow{2}{*}{$\begin{array}{l}\text { Обычно с повторе- } \\
\text { нием; чаще адреса- } \\
\text { том действия являет- } \\
\text { ся не жидкость, а } \\
\text { жидковатое веще- } \\
\text { ство }\end{array}$} \\
\hline & \begin{tabular}{|l|} 
«по грязи» \\
«по воде» \\
\end{tabular} & То же самое & $\begin{array}{l}\text { Частичное } \\
\text { погружение }\end{array}$ & То же самое & \\
\hline чмок & $\begin{array}{l}\text { «в грязь/-и» } \\
\text { «в воду/-е» }\end{array}$ & \begin{tabular}{|l} 
Среднее или \\
минимальное \\
количество \\
брызг; наличие \\
звука чмоканья \\
\end{tabular} & $\begin{array}{l}\text { Частичное } \\
\text { или полное } \\
\text { погружение }\end{array}$ & $\begin{array}{l}\text { Крупный } \\
\text { и/или тяже- } \\
\text { лый }\end{array}$ & $\begin{array}{l}\text { Чаще адресатом дей- } \\
\text { ствия является не } \\
\text { жидкость, а жидко- } \\
\text { ватое вещество }\end{array}$ \\
\hline
\end{tabular}

${ }^{1}$ При описании того или иного присущего водной ситуации звука с помощью однородного дескриптору коррелята (см., например, в табл. 2 звукоподражание чмок - звук чмоканья) мы исходим из свойства самоприменимости звукоподражаний (и их однокоренных слов), своим фонетическим составом призванных передавать воспринимаемый звук. 


\begin{tabular}{|c|c|c|c|c|c|}
\hline \multicolumn{2}{|c|}{ Дескриптор } & $\begin{array}{c}\text { Качество } \\
\text { столкновения }\end{array}$ & $\begin{array}{c}\text { Итог столк- } \\
\text { новения }\end{array}$ & Предмет & Примечание \\
\hline & $\begin{array}{l}\text { «по грязи» } \\
\text { «по воде» }\end{array}$ & То же самое & $\begin{array}{l}\text { Частичное } \\
\text { Погружение }\end{array}$ & То же самое & \\
\hline \multirow[t]{2}{*}{ шлеп } & «в воду» & \begin{tabular}{|l|} 
Большое или \\
среднее количе- \\
ство брызг, \\
наличие звука, \\
похожего на \\
шлепок
\end{tabular} & $\begin{array}{l}\text { Частичное } \\
\text { или полное } \\
\text { погружение }\end{array}$ & $\begin{array}{l}\text { Часто } \\
\text { упавший } \\
\text { плашмя }\end{array}$ & \multirow{2}{*}{$\begin{array}{l}\text { Жидкость только } \\
\text { иногда является ад- } \\
\text { ресатом действия }\end{array}$} \\
\hline & \begin{tabular}{|l} 
«на воду» \\
«по воде» \\
иногда с \\
повторени- \\
ем \\
\end{tabular} & То же самое & $\begin{array}{l}\text { Контакт, без } \\
\text { погружения }\end{array}$ & То же самое & \\
\hline \multirow{2}{*}{$\begin{array}{l}\text { нырк } \\
\text { (нырь) }\end{array}$} & «в воду» & \multicolumn{3}{|c|}{$\begin{array}{l}\text { Субъект (живое существо) изначально не } \\
\text { находится в жидкости или находится на ее } \\
\text { поверхности }\end{array}$} & \multirow{2}{*}{$\begin{array}{l}\text { Адресатом действия } \\
\text { может быть и не } \\
\text { жидкость }\end{array}$} \\
\hline & «под воду» & \multicolumn{3}{|c|}{\begin{tabular}{|l} 
Субъект изначально частично погружен в \\
жидкость или находится на ее поверхности
\end{tabular}} & \\
\hline
\end{tabular}

Т а бли ц а 2

Тип (b): ПРЕДМЕТ ЖИДКОСТЬ (из жидкости) =
ВСПЛЕСК, БРЫЗГИ И/ИЛИ ВОДНЫЙ ЗВУК

\begin{tabular}{|c|c|c|c|c|c|}
\hline \multicolumn{2}{|c|}{ Дескриптор } & $\begin{array}{c}\text { Качество взаи- } \\
\text { модействия }\end{array}$ & $\begin{array}{c}\text { Итог взаимо- } \\
\text { действия }\end{array}$ & Предмет & Примечание \\
\hline \multicolumn{6}{|c|}{ субъвект $\uparrow$ жидкость } \\
\hline буль & $\begin{array}{l}\text { «из во- } \\
\text { ды», «во- } \\
\text { да...» }\end{array}$ & \begin{tabular}{|l|} 
Минимальное \\
количество \\
брызг, наличие \\
булькающего \\
звука; образова- \\
ние лопающегося \\
пузырька воздуха \\
на поверхности \\
жидкости
\end{tabular} & $\begin{array}{l}\text { Выход на } \\
\text { поверхность } \\
\text { через толщу } \\
\text { жидкости }\end{array}$ & $\begin{array}{l}\text { Пузырь } \\
\text { воздуха } \\
\text { или газа }\end{array}$ & $\begin{array}{l}\text { Обычно с повторением; } \\
\text { Иногда исполнителем } \\
\text { действия мыслится } \\
\text { собственно жидкость; } \\
\text { Возможна замена слова } \\
\text { буль на слово бульк, } \\
\text { особенно при одно- } \\
\text { кратности или отрыви- } \\
\text { стости повторения дей- } \\
\text { ствия ситуации }\end{array}$ \\
\hline хлюп & $\begin{array}{l}\text { «из во- } \\
\text { ды», «во- } \\
\text { да...» }\end{array}$ & \begin{tabular}{|l|} 
Минимальное \\
количество \\
брызг, наличие \\
хлюпающего \\
звука; образова- \\
ние лопающегося \\
пузырька воздуха \\
на поверхности \\
жидкости \\
\end{tabular} & $\begin{array}{l}\text { Выход на } \\
\text { поверхность } \\
\text { через толщу } \\
\text { жидкости }\end{array}$ & $\begin{array}{l}\text { Пузырь } \\
\text { воздуха } \\
\text { или газа }\end{array}$ & $\begin{array}{l}\text { Иногда с повторением; } \\
\text { Иногда исполнителем } \\
\text { действия мыслится } \\
\text { собственно жидкость; } \\
\text { Часто составляющим } \\
\text { ситуации является не } \\
\text { жидкость, а жидковатое } \\
\text { вещество }\end{array}$ \\
\hline Чмок & $\begin{array}{l}\text { «из жи- } \\
\text { жи» }\end{array}$ & $\begin{array}{l}\text { Минимальное } \\
\text { количество брызг } \\
\text { или их отсут- } \\
\text { ствие; наличие } \\
\text { чмокающего }\end{array}$ & $\begin{array}{l}\text { Полный вы- } \\
\text { ход из толщи } \\
\text { или отрыв от } \\
\text { поверхности } \\
\text { жидковатого }\end{array}$ & $\left|\begin{array}{l}\text { Без особых } \\
\text { парамет- } \\
\text { ров }\end{array}\right|$ & $\begin{array}{l}\text { Чаще составляющим } \\
\text { ситуации является не } \\
\text { жидкость, а жидковатое } \\
\text { вещество }\end{array}$ \\
\hline
\end{tabular}




\begin{tabular}{|l|l|l|l|l|l|}
\hline \multicolumn{2}{|c|}{ Дескриптор } & $\begin{array}{c}\text { Качество взаи- } \\
\text { модействия }\end{array}$ & $\begin{array}{l}\text { Итог взаимо- } \\
\text { действия }\end{array}$ & Предмет & Примечание \\
\hline & $\begin{array}{l}\text { 3вука отделяю- } \\
\text { щегося от жид- } \\
\text { коватого веще- } \\
\text { ства (жидкости) } \\
\text { предмета }\end{array}$ & $\begin{array}{l}\text { вещества, } \\
\text { жидкости }\end{array}$ & & \\
\hline
\end{tabular}

Т а б л и ц а 3

Тип (с): ЖИДКОСТЬ $\rightarrow$ ПРЕДМЕТ (о преграду) и/или ЖИДКОСТЬ $\downarrow$ ПРЕДМЕТ (на поверхность) $=$ ВСПЛЕСК, БРЫЗГИ И/ИЛИ ВОДНЫЙ ЗВУК

\begin{tabular}{|c|c|c|c|c|c|}
\hline \multicolumn{2}{|c|}{$\begin{array}{c}(\text { преграда } \leftarrow) \text { жидкость } \rightarrow \\
\text { преграда }\end{array}$} & \multicolumn{2}{|c|}{ Дескриптор } & \multicolumn{2}{|c|}{ жидкость $\downarrow$ твердая поверхность } \\
\hline $\begin{array}{l}\text { Качество столк- } \\
\text { новения / прим. }\end{array}$ & Предмет & $\begin{array}{l}\text { «во что- } \\
\text { л.», «обо } \\
\text { что-л.» }\end{array}$ & $\begin{array}{c}\text { «на что- } \\
\text { л.» }\end{array}$ & $\begin{array}{l}\text { Особенность } \\
\text { жидкости }\end{array}$ & $\begin{array}{c}\text { Качество столкно- } \\
\text { вения / прим. }\end{array}$ \\
\hline $\begin{array}{l}\text { Звук бултыха- } \\
\text { ния / обычно с } \\
\text { повторением }\end{array}$ & \begin{tabular}{|l} 
Чаще \\
емкость, \\
преграда
\end{tabular} & \multicolumn{2}{|c|}{ бултых } & - & - \\
\hline Звук бульканья & $\begin{array}{l}\text { Емкость, } \\
\text { преграда }\end{array}$ & \multicolumn{2}{|c|}{ бульк } & - & - \\
\hline- & - & \multicolumn{2}{|c|}{ кап } & В виде капель & \begin{tabular}{|l|} 
Минимальное \\
количество брызг, \\
отрывистый рез- \\
кий звук / обычно \\
с повторением \\
\end{tabular} \\
\hline \begin{tabular}{|l} 
Звук от удара \\
плашмя, шлепка
\end{tabular} & $\begin{array}{l}\text { Преграда } \\
\text { (чаще } \\
\text { плоская), } \\
\text { емкость }\end{array}$ & \multicolumn{2}{|c|}{ плюх } & \begin{tabular}{|l} 
В виде крупных \\
капель или вы- \\
плеснугого разом \\
некоторого объема \\
жидкости, жидко- \\
ватой массы \\
\end{tabular} & $\begin{array}{l}\text { Возможно нали- } \\
\text { чие брызг; звук, } \\
\text { как от падения } \\
\text { чего-либо плашмя }\end{array}$ \\
\hline $\begin{array}{l}\text { Хлюпающий } \\
\text { звук /часто с } \\
\text { повторением }\end{array}$ & $\begin{array}{l}\text { Емкость } \\
\text { (часто } \\
\text { обувь), } \\
\text { преграда } \\
\end{array}$ & \multicolumn{2}{|c|}{ хлюп } & - & - \\
\hline Чмокающий звук & $\begin{array}{l}\text { Преграда } \\
\text { (чаще } \\
\text { плоская) }\end{array}$ & \multicolumn{2}{|c|}{ чмок } & $\begin{array}{l}\text { В виде жидкова- } \\
\text { той массы }\end{array}$ & \begin{tabular}{|l} 
Минимальное \\
количество брызг \\
или их отсутствие; \\
отрывистый чмо- \\
кающий звук
\end{tabular} \\
\hline Звук шлепка & $\begin{array}{l}\text { Преграда } \\
\text { (чаще } \\
\text { плоская) }\end{array}$ & \multicolumn{2}{|c|}{ шлеп } & \begin{tabular}{|l} 
В виде крупных \\
капель или вы- \\
плеснутого разом \\
некоторого объема \\
жидкости, жидко- \\
ватой массы \\
\end{tabular} & $\begin{array}{l}\text { Возможно нали- } \\
\text { чие брызг или их } \\
\text { отсутствие; звук, } \\
\text { как от шлепка }\end{array}$ \\
\hline $\begin{array}{l}\text { Звук, как от } \\
\text { хлесткого удара }\end{array}$ & Преграда & \multicolumn{2}{|c|}{ хлесть (хлесь) } & $\begin{array}{l}\text { В виде сильной } \\
\text { струи или резко и } \\
\text { разом выплесну- } \\
\text { того некоторого } \\
\text { объема жидкости } \\
\end{array}$ & $\begin{array}{l}\text { Наличие брызг; } \\
\text { звук, как от хлест- } \\
\text { кого удара }\end{array}$ \\
\hline
\end{tabular}


Тип (d): ПРЕДМЕТ (источник) ЭЖИДКОСТЬ =

Т а б л и ц а 4 СТРУЯ, БРЫЗГИ И/ИЛИ ВОДНЫЙ ЗВУК

\begin{tabular}{|c|c|c|c|c|}
\hline \multicolumn{5}{|c|}{ источник 马 жидкость } \\
\hline \multicolumn{2}{|c|}{ Дескриптор } & $\begin{array}{c}\text { Качество взаимо- } \\
\text { действия }\end{array}$ & $\begin{array}{c}\text { Особенность } \\
\text { жидкости }\end{array}$ & Примечание \\
\hline буль & $\begin{array}{l}\text { «из чего- } \\
\text { л.» }\end{array}$ & Булькающий звук & $\begin{array}{l}\text { В виде не- } \\
\text { ровной, } \\
\text { сбивчивой } \\
\text { струи }\end{array}$ & $\begin{array}{l}\text { Обычно с повторением; источ- } \\
\text { ник часто узкогорлый; проис- } \\
\text { хождение звука может быть } \\
\text { осмыслено в русле значения } \\
\text { слова буль типа (b) }\end{array}$ \\
\hline кап & $\begin{array}{l}\text { «из чего- } \\
\text { л.» }\end{array}$ & \begin{tabular}{|l} 
Звук связан с ре- \\
зультатом дей- \\
ствия в ситуации - \\
падением капель \\
на поверхность \\
\end{tabular} & $\begin{array}{l}\text { В виде ка- } \\
\text { пель }\end{array}$ & - \\
\hline пшик & $\begin{array}{l}\text { «из чего- } \\
\text { л.» }\end{array}$ & $\begin{array}{l}\text { Наличие шипяще- } \\
\text { го звука }\end{array}$ & $\begin{array}{l}\text { В виде мелко } \\
\text { и широко } \\
\text { распыленной } \\
\text { струи }\end{array}$ & $\begin{array}{l}\text { Источник - часто мелкое от- } \\
\text { верстие; жидкость часто похо- } \\
\text { жа на струю газа; составляю- } \\
\text { щим ситуации может быть не } \\
\text { только жидкость }\end{array}$ \\
\hline $\begin{array}{l}\text { хлесть } \\
\text { (хлесь) }\end{array}$ & \begin{tabular}{|l} 
«из чего- \\
л.»
\end{tabular} & $\begin{array}{l}\text { Звук зависит от } \\
\text { особенностей } \\
\text { струи выходящей } \\
\text { жидкости }\end{array}$ & $\begin{array}{l}\text { В виде силь- } \\
\text { ной, брызга- } \\
\text { ющей струи }\end{array}$ & - \\
\hline
\end{tabular}

Развивая последнюю мысль, можно с большой долей вероятности допустить существование исчерпывающего списка известных человеку типичных водных ситуаций и, как следствие, присущих им водных звуков. Если это предположение верно, то всякая актуализация в лексике какого-либо языка некоторого подмножества водных ситуаций из такого перечня будет частной системой водной лексики такого языка. Также может оказаться, что по тем или иным историческим, языковым или географическим причинам перечень актуальных водных ситуаций, отраженных в одном языке, может отличаться от перечня и специфики отражения водных ситуаций в другом. Так, рассмотрев с этих позиций звукоподражательные междометия из водной лексики русского языка, интересно обратиться к подобной практике финского языка. Какова же частная система типичных водных ситуаций и водных звукоподражательных междометий финского языка и актуальны ли для него выделенные нами критерии обобщения и различения водных звукоподражательных междометий?

\section{Водные звукоподражательные междометия финского языка (на основе электронного анкетирования)}

К водным звукоподражательным междометиям в финском языке относятся следующие слова: kohi, kuoh, liri, liti, lits, loiskis, loti, läti, läts, molskis, pirsk, pläts, polskis, pori, pul(i), roiskis, tip. Как уже было упомянуто выше, 
зафиксированность финских звукоподражательных междометий невозможно определить по словарным данным. В современных толковых словарях Suomen kielen perussanakirja («Базовый словарь финского языка», 3 тома, около 100000 словарных статей 1990-1994 гг.) [20] и Kielitoimiston sanakirja («Словарь языкового бюро Центра Отечественных языков Финляндии», более 100000 словарных статей, версия от 2016 г.a ${ }^{1}$ [21] нет ни одного из этих междометий. Существует еще и Nykysuomen sanakirja («Словарь современного финского языка» в шести томах от 1951-1961 гг., новейшее издание: [22]), содержащий более 200000 словарных статей и считающийся до сих пор авторитетным, но несколько устаревшим, поскольку большая часть его материалов была собрана еще в первой половине ХХ в. Из вышеупомянутых междометий он содержит loiskis, molskis, polskis u roiskis.

\section{Описание электронного анкетирования}

Поскольку водные звукоподражательные междометия финского языка не описаны в словарях, было проведено электронное анкетирование носителей языка в Интернете (с помощью программы Webropol). Анкетирование проводилось среди студентов филологического профиля (главный предмет: финский или английский язык) Университета Турку (Финляндия). Студентов пригласили принять участие в исследовании через студенческую рассылку, и в течение трех дней было получено 124 ответа (среди которых 19 - от мужчин, 105 - от женщин). Все респонденты являлись носителями финского языка. Испытуемые были в возрасте 18--66 лет (109 из 124 - в возрасте до 29 лет).

Анкетирование было проведено с учетом максимального удобства респондентов - на все обязательные вопросы можно было ответить, выбирая между готовыми вариантами, а комментирование было во всех случаях добровольным. Таким образом, даже если в анкете было достаточно много вопросов, ее можно было заполнить примерно за 15 минут (указать возраст, место рождения и место жительства и кликнуть мышью в общей сложности около ста раз). Те, кто решил что-либо прокомментировать, мог потратить и намного больше времени.

Электронная анкета состояла из трех типов заданий. Первый тип - субституционный тест, содержащий серии предложений, в которых в одном и том же предложении употреблялись близкие по значению водные звукоподражания. У респондентов спросили, «можно ли так сказать по-фински», и у них было три варианта ответа для каждого предложения - «естественно», «неестественно» и «я бы сам(а) так не сказал(а), но кто-нибудь другой мог бы так сказать». При анализе варианты «естественно» и вариант «я бы сам(а) так не...» считались фактически равноценными - на наш взгляд, они

\footnotetext{
${ }^{1}$ Данный словарь является новой версией Suomen kielen perussanakirja. Новые версии этого словаря выпускаются в Интернете примерно раз в год.
} 
одинаково подтверждают возможность использования. Вторым типом заданий в опросе были отдельные предложения, которые являлись либо предположительно естественными, либо примерами менее удачного употребления. Третий тип заданий тестировал признаки, факторы, лежащие, по нашему предположению, в основе различий водных звукоподражаний между собой. Для каждого из признаков (например, «является ли предмет плоским?») в связи с тем или иным междометием респондентам были предложены варианты ответа «да», «нет» и «здесь не имеет значения». В тест были включены следующие признаки: 1) серийность: повторяется ли звук (и, соответственно, слово); 2) место звука: водный звук от взаимодействия предмета с толщей жидкости или с ее поверхностью, прослойкой; 3) форма предмета, который взаимодействует с жидкостью (плоскостной или нет); 4) итог взаимодействия: происходит ли полное погружение предмета в толщу жидкости или нет; 5) качество взаимодействия с жидкостью.

\section{Значения финских звукоподражательных междометий (на основе анкетирования)}

Ниже будут представлены водные звукоподражательные междометия финского языка на основе результатов проведенного электронного анкетирования. Опишем сначала две группы слов с похожими значениями, а затем остальные слова в алфавитном порядке. Из финских водных звукоподражательных междометий близкими по значению являются, с одной стороны, lits, läts и pläts и loiskis, molskis, polskis, roiskis - с другой. Первая группа слов явно звукоподражательная, а вторая - звукоподражательная и глагольная.

Lits обозначает звук, связанный с падением какого-либо предмета на твердую поверхность, или звук, который производит вода при соприкосновении воды с большим предметом, например когда человек шагает в лужу. Läts является его близким синонимом. На вопрос, обозначают ли эти два слова один и тот же звук или разные звуки, $89 \%$ респондентов ответили, что слова обозначают либо одно и то же, либо почти одно и то же. Эти звукоподражания обозначают единичный звук, но могут быть употреблены и для повтора такого звука. Респонденты считали, что эти слова связаны с прикосновением с водой, только 5\% в отношении lits и $4 \%$ в отношении läts ответили, что слово может быть употреблено в случае, если источником звука является только вода без контакта с каким-либо предметом. Для обоих слов плоскость предмета является важным фактором, и, как отметили респонденты, эти слова могут быть употреблены в отношении плавания, только если речь идет о неудачном прыжке в воду таким образом, что человек оказывается в воде на животе, т.е. в положении плоского предмета. Слова нередко встречаются и в комбинации lits läts. Например: Lits läts läts kuuluu lätäköstä kun lapsi hyppii siinä (Lits-läts-läts - слышно из лужи, когда в ней прыгает ребенок). Saappaat sanovat lits läts (Сапоги говорят lits-läts).

Pläts и его вариант plätsis 'плюх, бултых' обозначают звук от контакта воды или мокрого предмета с твердой поверхностью или с водой. 
Примеры: Pläts. Kaadun naama edellä mutavelliin (Плюх. Упал(а) в грязь). Pläts! Pläts! Leikkivene iskeytyi veteen (Плюх! Плюх! Игрушечный кораблик столкнулся с водой.) В данном случае повтор является маркированным, так как по своему первичному значению междометие обозначает единичное действие и поэтому в финском языке может быть употреблено с повтором, только если подчеркивается повтор громкого звука.

Loisk и его вариант loiskis обозначают звук, связанный с плеском воды. Данное междометие имеет много различных употреблений, оно указывает на плеск независимо от того, кто и или что этот плеск вызывает. Например: Avaimet tippuivat loiskis vaan veteen (Ключи просто упали в воду - loiskis). Molskis обозначает звук, связанный с падением какого-либо предмета в воду. Главное здесь именно то, что предмет оказывается в воде, а конкретный звук или плеск имеют меньшее значение. Предмет должен быть достаточно большим, так это может быть человек или рыба. Например: Molskis! Lapsi pyllähti veteen (Molskis! Ребенок упал в воду); Molskis vaan veteen siitä! (Идите прямо в воду, molskis!). Roiskis и его вариант roisk обозначают звук, связанный с брызгами. Слово употребляется в разных водных ситуациях, но при этом особое внимание обращается на брызги. В этом случае вариант без -is может обозначать и намеренное и ненамеренное действие, в то время как roisk - только намеренное действие, т.е. употребление без суффикса представляет собой более глагольное, что заметно и в синтаксических возможностях. Примеры: Varo vaan, ettet saa vettä päällesi, roisk, roisk (Осторожно, смотри, чтобы на тебя не попала вода, roisk, roisk); Lapsi hyppäsi roiskis vaan kuralammikkoon (Ребенок прыгнул в лужу - roiskis).

Результаты субституционного теста показали, что для loiskis и roiskis главное - брызги. Кроме того, в случае loiskis брызги никакого вреда не приносят, а в случае roiskis они оказываются на ком-либо. Для polskis обязательно, чтобы в воде оказался не предмет, а одушевленный объект, Наиболее вероятно, человек. Pläts обозначает, скорее всего, брызги, вызванные плоским предметом на поверхности воды. Для molskis главное - погружение. Из перечисленных междометий polskis в большей мере ограничено по употреблению для обозначения резкого контакта с водой. Такой результат анкетирования напомнил авторам о том, что даже если слово может быть употреблено как близкий синоним других слов в этой группе, его наиболее прототипичным употреблением является, скорее, движение в воде, чем в воду, как и у однокоренного глагола polskia 'плескаться, купаться'. Связь слова roiskis именно с (намеренными) брызгами много раз отмечалась респондентами: брызги либо отсутствуют, либо не имеют значения.

По данным анкетирования, loiskis из этих пяти слов имеет самое общее значение. Molskis тоже имеет общее значение, но его употребление в случае, когда никакого погружения нет, может быть затруднительно.

Согласно ответам респондентов финское слово kohi обозначает звук волн или ветра. Действие, которое вызывает звук, является постоянным, например, это может быть непрерывная струя воды. Однокоренным является глагол kohista 'бушевать'. Согласно ответам $76 \%$ респондентов звук не 
может быть вызван соприкосновением с предметом, здесь действует только вода как таковая, а 20\% считают, что звук связан либо с прикосновением к предмету, либо только с движением воды. Только 4\% ответили, что звук обязательно вызван соприкосновением с предметом. Соответственно, относительно единое мнение преобладало и по поводу того, что такие признаки, как погружение и форма предмета, не имеют при этом значения. $K o h i-$ хороший пример слова, о котором невозможно найти информацию другими способами - его не только нет в словарях, но и поиск в Интернете дает на 95\% не то (иностранные имена собственные), и в электронных корпусах данного слова также нет.

Слово kuoh обозначает либо звук волн, либо звук жидкости (компота, киселя), связанный с кипением. Это слово также связано со звуком (единичным или повторяющимся), который слышен, когда пена или пузырек поднимаются на поверхность жидкости, и который сопровождается визуальными эффектами. Звук производится без соприкосновения с другими предметами. Слово имеет и фигуративное значение 'возбуждение'. Однокоренными являются глаголы kuоhua 'пениться, кипеть, бурлить' и kuohahtaa 'вскипеть, перелиться, вспыхнуть'. Например, Ja sitten yllättäen kuoh! ja keitos oli täydessä vauhdissa (А потом вдруг kuoh! - и закипел).

$\operatorname{Lir}(i)$ обозначает звук движения (струи) небольшого количества воды или жидкости, например, когда вода течет из крана, струится в ручье или выливается из одного сосуда в другой: Vesi lirisee purossa liri liri (Вода течет в ручье - liri-liri). Liri liri pontikka lirisi ostajan pulloon. (Liri-liri - самогонка текла в бутылку покупателя). В примерах вместе с междометием также употребляется однокоренной звукоподражательный глагол liristä. Из разных вариантов ответа 96\% респондентов в качестве значения этого слова выбрали «текущую воду», 90\% ответили, что звук может повторяться, и 95\% - что предмет погружается в воду или что погружение не имеет здесь значения. Респонденты также были практически на $100 \%$ согласны с тем, что звук производится близко к поверхности воды (79\%) или что это не имеет здесь значения (20\%). Большая часть респондентов также ответили, что звук вызван только водой, но не контактом с другими предметами и что форма предмета не имеет значения.

Liti - звук, связанный с промокшим предметом при столкновении с преградой. Loti обозначает повторяющийся хлюпающий звук, вызванный большим предметом. Например: Loti loti kuului saappaiden alta (Loti, lotiбыло слышно из-под сапог). Läti обозначает повторяющийся звук, менее резкий, чем lits или läts, и также не связанный с брызгами. Звук вызывается большим предметом (таким как сапог). Например: Läti, läti, läti kuului kun pieni saapas läiskytteli jään päällä olevaa vettä (Läti, läti, läti слышалось, когда маленький сапожок шлепал в воде на льду). В этом же предложении можно было употребить и liti или loti или их комбинации. Эти три слова близки по значению и могут быть употреблены вместе. Разница между loti и läti в том, что при том, что звук может быть иденти- 
чен, läti с большей вероятностью, чем loti, связан с брызгами. Не все носители финского языка, однако, различают их. Эти слова связаны с однокоренными глаголами litistä, lotista, lätistä ${ }^{1}$, которые все можно перевести как 'хлюпать'.

Pirsk ' $\approx$ пшик' обозначает звук, вызванный тем, как вода или другая жидкость с шипением вырывается откуда-либо. Например: Pirsk. Hajuveden tuoksu levisi huoneeseen. (Pirsk. Запах духов распространился по всей комнате). Äiti silitti veljen paitaa: pirsk, pirsk. (Мама гладила брату рубашку-pirsk-pirsk.)

Pori, образованное от глагола porista 'клокотать', обозначает звук (скоpee, бурного) кипения воды, других жидкостей или полужидких продуктов (например, каши). Например: Pori pori kuului kattilasta (Из кастрюли было слышно pori-pori).

Pul(i) означает звук, издаваемый пузырящейся водой или ручьем. Такой звук вызван контактом воздуха и потока воды, в котором из-за его неравномерности образуются пузыри. Несмотря на значительное фонетическое сходство данного звукоподражания с русским словом «буль» (оба чаще всего встречаются в конструкциях с повтором), они не являются идентичными по употреблению. Финское puli связано со свободно струящейся водой и из-за этого чаще всего употребляется по отношению к тому, что происходит весной. Это слово не может быть употреблено в отношении единичного случая бульканья, звук (и соответствующее ему водное действие) должен продолжаться и повторяться. Puro sanoi puli-puli (Ручей говорит буль-буль).

Звукоподражательное междометие tip обозначает звук капающей жидкости и похоже на русское слово с соответствующим значением (кап). Это слово нередко употребляется с повтором: tip, tip, tip или tip-tip ${ }^{2}$. Например, в качестве наречия (как): Vettä tiputtelee hanasta tip, tip (Вода капает из крана - tip, tip), в качестве субъекта или объекта при описании звучания: Hiljainen tip tip kuului katolta (С крыши было слышно тихое tip, tip). Ответы респондентов (что для нас оказалось несколько неожиданным) свидетельствуют о том, что звук необязательно вызывается именно каплями - это слово может быть употреблено, когда бросают, например, камушки в воду.

Опираясь на ответы респондентов, поместим финские водные звукоподражательные междометия в таблицы, аналогичные русским (табл. 5-8).

${ }^{1}$ Lätistä употребляется также в переносном значении, 'болтать', 'молоть ерунду'. Весьма интересно, что оно, как и 'болтать', в первом значении связано с водой.

${ }^{2}$ Существует и комбинация tip-tap, или tip-tap-tip-tap-tipe-tipe-tip-tap, которая, похоже, не описывает воду, но знакома всем финнам из детской рождественской песни, в которой она сопровождается определенной игрой указательными пальцами. Что эта комбинация там обозначает, похоже, никто не знает. Кроме того, существует также комбинация tip top, которая имеет значение безупречности (порядка, наряда и т.д.). 
Т а бл и ц а 5

Тип (а): ПРЕДМЕТ $\downarrow$ ЖИДКОСТЬ (в жидкость, на жидкость, по жидкости) = ВСПЛЕСК, БРЫЗГИ И/ИЛИ ВОДНЫЙ ЗВУК

\begin{tabular}{|c|c|c|c|c|c|}
\hline \multicolumn{2}{|c|}{ Дескриптор } & \begin{tabular}{|c|} 
Качество \\
столкновения
\end{tabular} & $\begin{array}{c}\text { Итог столк- } \\
\text { новения } \\
\end{array}$ & Предмет & Примечание \\
\hline \multicolumn{6}{|c|}{ субъъект $(\rightarrow$ объект) $\downarrow$ жидкость } \\
\hline $\begin{array}{l}\text { loiskis, } \\
\text { loisk }\end{array}$ & $\begin{array}{l}\text { «в воду» } \\
\text { «по воде», } \\
\text { иногда с по- } \\
\text { вторением }\end{array}$ & $\begin{array}{l}\text { Среднее или } \\
\text { большое ко- } \\
\text { личество } \\
\text { брызг }\end{array}$ & $\begin{array}{l}\text { Частичное } \\
\text { или полное } \\
\text { погружение }\end{array}$ & $\begin{array}{l}\text { Любой } \\
\text { предмет }\end{array}$ & \begin{tabular}{|l} 
Главное - брызги, \\
от глаголов loiskia \\
'брызгать', \\
loiskahtaa \\
'брызнуть' \\
\end{tabular} \\
\hline molskis & «в воду» & \begin{tabular}{|l|} 
Маленькое, \\
среднее или \\
большое ко- \\
личество \\
брызг, гром- \\
кий звук \\
\end{tabular} & $\begin{array}{l}\text { Частичное } \\
\text { погружение }\end{array}$ & $\begin{array}{l}\text { Большой, } \\
\text { скорее, } \\
\text { одушевлен- } \\
\text { ный }\end{array}$ & $\begin{array}{l}\text { Главное - оказаться } \\
\text { в воде и звук, свя- } \\
\text { занный с этим }\end{array}$ \\
\hline $\begin{array}{l}\text { roiskis, } \\
\text { roisk }\end{array}$ & | «по воде» & $\begin{array}{l}\text { Среднее или } \\
\text { большое ко- } \\
\text { личество } \\
\text { брызг } \\
\end{array}$ & $\begin{array}{l}\text { Нет погру- } \\
\text { жения }\end{array}$ & Большой & \begin{tabular}{|l} 
Брызги важнее зву- \\
ка, от глагола \\
roiskia, roiskuttaa \\
'брызгать'
\end{tabular} \\
\hline polskis & 《в воде» & $\begin{array}{l}\text { Маленькое, } \\
\text { среднее или } \\
\text { большое ко- } \\
\text { личество } \\
\text { брызг, движе- } \\
\text { ние воды } \\
\end{array}$ & $\begin{array}{l}\text { Частичное } \\
\text { погружение }\end{array}$ & $\begin{array}{l}\text { Человек, } \\
\text { иногда так- } \\
\text { же предме- } \\
\text { ты }\end{array}$ & $\begin{array}{l}\text { Действие часто } \\
\text { намеренное, в фо- } \\
\text { кусе внимания не } \\
\text { брызги, а движение } \\
\text { в воде или в воду }\end{array}$ \\
\hline \multirow[b]{2}{*}{ pläts } & |«в воду» & $\begin{array}{l}\text { Большое или } \\
\text { среднее коли- } \\
\text { чество брызг, } \\
\text { наличие звука, } \\
\text { похожего на } \\
\text { шлепок }\end{array}$ & $\begin{array}{l}\text { Частичное } \\
\text { или полное } \\
\text { погружение }\end{array}$ & $\begin{array}{l}\text { Любой } \\
\text { предмет }\end{array}$ & \multirow{2}{*}{$\begin{array}{l}\text { Обычно адресатом } \\
\text { действия является } \\
\text { жидкость, но может } \\
\text { быть и твердая по- } \\
\text { верхность }\end{array}$} \\
\hline & $\begin{array}{l}\text { «на воду» } \\
\text { «по воде», } \\
\text { иногда с по- } \\
\text { вторением }\end{array}$ & То же самое & $\begin{array}{l}\text { Контакт, без } \\
\text { погружения }\end{array}$ & $\begin{array}{l}\text { Любой } \\
\text { предмет, } \\
\text { если боль- } \\
\text { шой, то } \\
\text { часто упав- } \\
\text { ший плаш- } \\
\text { мя } \\
\end{array}$ & \\
\hline \multirow[t]{2}{*}{ lits, läts } & $\begin{array}{l}\text { «по воде» } \\
\text { «на поверх- } \\
\text { ность», часто } \\
\text { с повторени- } \\
\text { ем }\end{array}$ & $\begin{array}{l}\text { Среднее или } \\
\text { минимальное } \\
\text { количество } \\
\text { брызг, слабый } \\
\text { звук, связан- } \\
\text { ный с брызга- } \\
\text { ми }\end{array}$ & $\begin{array}{l}\text { Контакт с } \\
\text { поверхно- } \\
\text { стью }\end{array}$ & $\begin{array}{l}\text { Любого } \\
\text { размера, } \\
\text { часто упав- } \\
\text { ший плаш- } \\
\text { мя }\end{array}$ & \\
\hline & \begin{tabular}{|l} 
«в воду/-е», \\
«в грязь/-и», \\
часто с по- \\
вторением \\
\end{tabular} & \begin{tabular}{|l} 
Среднее или \\
минимальное \\
количество \\
брызг, слабый
\end{tabular} & $\begin{array}{l}\text { Контакт с } \\
\text { дном водое- } \\
\text { ма, бассейна, } \\
\text { таза и т.д. } \\
\end{array}$ & $\begin{array}{l}\text { Небольшой, } \\
\text { например, } \\
\text { нога, рука } \\
\text { или сапог }\end{array}$ & $\begin{array}{l}\text { Водоем должен } \\
\text { быть неглубоким } \\
\text { (например, лужа, } \\
\text { невысокий берег); }\end{array}$ \\
\hline
\end{tabular}




\begin{tabular}{|c|c|l|c|c|c|}
\hline \multicolumn{2}{|c|}{ Дескриптор } & $\begin{array}{c}\text { Качество } \\
\text { столкновения }\end{array}$ & $\begin{array}{l}\text { Итог столк- } \\
\text { новения }\end{array}$ & Предмет & Примечание \\
\hline & & $\begin{array}{l}\text { звук, связан- } \\
\text { ный с брызга- } \\
\text { ми }\end{array}$ & & & $\begin{array}{l}\text { также обобщенный } \\
\text { звук слабых брызг }\end{array}$ \\
\hline
\end{tabular}

Т а бл и ц а 6

Тип (b): ПРЕДМЕТ $\uparrow$ ЖИДКОСТЬ (из жИДКости) = ВСПЛЕСК, БРЫЗГИ И/ИЛИ ВОДНЫЙ ЗВУК

\begin{tabular}{|c|c|c|c|c|c|}
\hline \multicolumn{2}{|c|}{ Дескриптор } & $\begin{array}{c}\text { Качество взаимо- } \\
\text { действия }\end{array}$ & $\begin{array}{l}\text { Итог взаимо- } \\
\text { действия }\end{array}$ & $\begin{array}{c}\text { Пред- } \\
\text { мет }\end{array}$ & Примечание \\
\hline \multicolumn{6}{|c|}{ субъект $\uparrow$ жидкость } \\
\hline puli & \begin{tabular}{|l} 
«из во- \\
ды» \\
«во- \\
да...»
\end{tabular} & $\begin{array}{l}\text { Минимальное } \\
\text { количество брызг, } \\
\text { наличие булька- } \\
\text { ющего звука; об- } \\
\text { разование лопаю- } \\
\text { щегося пузырька } \\
\text { воздуха на по- } \\
\text { верхности жидко- } \\
\text { сти }\end{array}$ & $\begin{array}{l}\text { Выход на по- } \\
\text { верхность че- } \\
\text { рез толщу } \\
\text { жидкости }\end{array}$ & $\begin{array}{l}\text { Пузырь } \\
\text { воздуха } \\
\text { или газа }\end{array}$ & $\begin{array}{l}\text { Не о кипении, обычно с } \\
\text { повторением; иногда } \\
\text { исполнителем действия } \\
\text { мыслится собственно } \\
\text { жидкость }\end{array}$ \\
\hline pori & $\mid \begin{array}{l}\text { «из во- } \\
\text { ды» } \\
\text { «во- } \\
\text { да...» }\end{array}$ & $\begin{array}{l}\text { Минимальное } \\
\text { количество брызг, } \\
\text { наличие булька- } \\
\text { ющего звука; об- } \\
\text { разование лопаю- } \\
\text { щегося пузырька } \\
\text { воздуха на по- } \\
\text { верхности жидко- } \\
\text { сти }\end{array}$ & $\begin{array}{l}\text { Выход на по- } \\
\text { верхность че- } \\
\text { рез толщу } \\
\text { жидкости }\end{array}$ & $\begin{array}{l}\text { Пузырь } \\
\text { воздуха } \\
\text { или газа }\end{array}$ & $\begin{array}{l}\text { Звук кипения воды, жид- } \\
\text { кости или жидковатого } \\
\text { вещества; обычно с по- } \\
\text { вторением; иногда ис- } \\
\text { полнителем действия } \\
\text { мыслится собственно } \\
\text { жидкость }\end{array}$ \\
\hline $\begin{array}{l}\text { liti, } \\
\text { loti, } \\
\text { läti }\end{array}$ & \begin{tabular}{|l} 
«из во- \\
ды» \\
«во- \\
да...»
\end{tabular} & $\begin{array}{l}\text { Минимальное } \\
\text { количество брызг, } \\
\text { наличие хлюпаю- } \\
\text { щего звука }\end{array}$ & $\begin{array}{l}\text { Выход на по- } \\
\text { верхность че- } \\
\text { рез толщу } \\
\text { жидкости }\end{array}$ & $\mid \begin{array}{l}\text { Без } \\
\text { особых } \\
\text { пара- } \\
\text { метров }\end{array}$ & $\begin{array}{l}\text { Часто с повторением; } \\
\text { иногда исполнителем } \\
\text { действия мыслится соб- } \\
\text { ственно жидкость; часто } \\
\text { составляющим ситуации } \\
\text { является не жидкость, а } \\
\text { полужидкое вещество } \\
\end{array}$ \\
\hline loiskis & $\mid \begin{array}{l}\text { «из во- } \\
\text { ды» }\end{array}$ & $\begin{array}{l}\text { Среднее или } \\
\text { большое количе- } \\
\text { ство брызг }\end{array}$ & $\begin{array}{l}\text { Выход на по- } \\
\text { верхность во- } \\
\text { ды с брызгами }\end{array}$ & \begin{tabular}{|l} 
Без \\
особых \\
пара- \\
метров
\end{tabular} & $\begin{array}{l}\text { Однократность и момен- } \\
\text { тальность действия }\end{array}$ \\
\hline kuoh & $\begin{array}{l}\text { «из } \\
\text { жидко- } \\
\text { сти, } \\
\text { жид- } \\
\text { кость..» }\end{array}$ & $\begin{array}{l}\text { Звук пены или } \\
\text { капель, поднима- } \\
\text { ющихся на по- } \\
\text { верхность }\end{array}$ & $\begin{array}{l}\text { Полный выход } \\
\text { из толщи или } \\
\text { отрыв от по- } \\
\text { верхности } \\
\text { полужидкого } \\
\text { вещества, } \\
\text { жидкости }\end{array}$ & $\begin{array}{l}\text { Лопа- } \\
\text { ющийся } \\
\text { пузырь } \\
\text { воздуха } \\
\text { или газа }\end{array}$ & $\begin{array}{l}\text { Употребляется часто и в } \\
\text { фигуративном значении } \\
\text { состояния кипения об- } \\
\text { щества }\end{array}$ \\
\hline
\end{tabular}


Т а б л и ц а 7

Тип (с): ЖИДКОСТЬ $\rightarrow$ ПРЕДМЕТ (о преграду) и/или ЖИДКОСТЬ $\downarrow$ ПРЕДМЕТ (на поверхность) = ВСПЛЕСК, БРЫЗГИ И/ИЛИ ВОДНЫЙ ЗВУК

\begin{tabular}{|c|c|c|c|c|c|}
\hline \multicolumn{2}{|c|}{$\begin{array}{c}(\text { преграда } \leftarrow) \text { жидкость } \rightarrow \\
\text { преграда } \\
\end{array}$} & \multicolumn{2}{|c|}{ Дескриптор } & \multicolumn{2}{|c|}{ жидкость $\downarrow$ твердая поверхность } \\
\hline $\begin{array}{l}\text { Качество столк- } \\
\text { новения / прим. }\end{array}$ & Предмет & $\begin{array}{l}\langle\ll В \text { чТО-Л.» } \\
\text { «обо } \\
\text { чТО-Л.» }\end{array}$ & $\begin{array}{l}\text { «на что- } \\
\text { л.» }\end{array}$ & $\begin{array}{c}\text { Особенность } \\
\text { жидкости }\end{array}$ & $\begin{array}{c}\text { Качество столкно- } \\
\text { вения / прим. }\end{array}$ \\
\hline- & - & \multicolumn{2}{|c|}{ tip } & В виде капель & $\begin{array}{l}\text { Минимальное } \\
\text { количество брызг, } \\
\text { отрывистый рез- } \\
\text { кий звук / обычно } \\
\text { с повторением }\end{array}$ \\
\hline $\begin{array}{l}\text { Звук от удара } \\
\text { плашмя, шлепка }\end{array}$ & $\begin{array}{l}\text { Преграда, } \\
\text { емкость }\end{array}$ & lois & (is) & $\begin{array}{l}\text { В виде крупных } \\
\text { капель или вы- } \\
\text { плеснутого разом } \\
\text { некоторого объ- } \\
\text { ема жидкости, } \\
\text { жидковатой мас- } \\
\text { сы } \\
\end{array}$ & $\begin{array}{l}\text { Возможно нали- } \\
\text { чие брызг; звук, } \\
\text { как от падения } \\
\text { чего-либо плашмя }\end{array}$ \\
\hline $\begin{array}{l}\text { Звук от удара } \\
\text { плашмя, шлепка }\end{array}$ & \begin{tabular}{|l} 
Преграда \\
(чаще \\
плоская), \\
емкость
\end{tabular} & $\mathrm{pl}$ & & $\begin{array}{l}\text { В виде крупных } \\
\text { капель или вы- } \\
\text { плеснутого разом } \\
\text { некоторого объ- } \\
\text { ема жидкости, } \\
\text { полужидкой мас- } \\
\text { сы }\end{array}$ & $\begin{array}{l}\text { Возможно нали- } \\
\text { чие брызг }\end{array}$ \\
\hline $\begin{array}{l}\text { Звук от удара } \\
\text { плашмя, шлепка }\end{array}$ & $\begin{array}{l}\text { Преграда } \\
\text { (чаще } \\
\text { плоская), } \\
\text { емкость } \\
\end{array}$ & lits, & läts & - & - \\
\hline Звук волн & $\begin{array}{l}\text { Преграда } \\
\text { (берег, } \\
\text { камень) }\end{array}$ & $\mathrm{ku}$ & & - & - \\
\hline
\end{tabular}

Т а бл и ц 8

Тип (d): ПРЕДМЕТ (источник) Э ЖИДКОСТЬ = СТРУЯ, БРЫЗГИ И/ИЛИ ВОДНЫЙ ЗВУК

\begin{tabular}{|c|c|c|c|c|}
\hline \multicolumn{2}{|c|}{ Дескриптор } & $\begin{array}{c}\text { Качество } \\
\text { взаимодействия }\end{array}$ & $\begin{array}{l}\text { Особенность } \\
\text { жидкости }\end{array}$ & Примечание \\
\hline \multicolumn{5}{|c|}{ источник 马 жидкость } \\
\hline tip & \begin{tabular}{|l} 
«из чего- \\
л.»
\end{tabular} & $\begin{array}{l}\text { Звук связан с резуль- } \\
\text { татом действия в } \\
\text { ситуации - падением } \\
\text { капель на поверх- } \\
\text { ность }\end{array}$ & $\begin{array}{l}\text { В виде ка- } \\
\text { пель }\end{array}$ & $\begin{array}{l}\text { По значению и употреблению } \\
\text { очень близко русскому слову } \\
\text { каn }\end{array}$ \\
\hline liri & $\begin{array}{l}\text { «жид- } \\
\text { кость...», } \\
\text { «из чего- } \\
\text { л.» }\end{array}$ & $\begin{array}{l}\text { Звук маленькой } \\
\text { струи }\end{array}$ & $\begin{array}{l}\text { В виде по- } \\
\text { стоянной, } \\
\text { ровной, ма- } \\
\text { ленькой } \\
\text { струи }\end{array}$ & $\begin{array}{l}\text { Например, из крана, при пере- } \\
\text { ливании }\end{array}$ \\
\hline
\end{tabular}




\begin{tabular}{|l|l|l|l|l|}
\hline \multicolumn{2}{|c|}{ Дескриптор } & \multicolumn{1}{|c|}{$\begin{array}{c}\text { Качество } \\
\text { взаимодействия }\end{array}$} & $\begin{array}{l}\text { Особенность } \\
\text { жидкости }\end{array}$ & Примечание \\
\hline loisk & $\begin{array}{l}\text { «из чего- } \\
\text { л.» }\end{array}$ & $\begin{array}{l}\text { Звук зависит от осо-- } \\
\text { бенностей струи } \\
\text { выходящей жидкости }\end{array}$ & $\begin{array}{l}\text { В виде силь- } \\
\text { ной, брызга- } \\
\text { Ющей струи }\end{array}$ & \\
\hline kohi & $\begin{array}{l}\text { Звук воды или воз- } \\
\text { духа в движении без } \\
\text { взаимодействия с } \\
\text { предметами }\end{array}$ & $\begin{array}{l}\text { В виде ров- } \\
\text { ной струи }\end{array}$ & Звук на фоне \\
\hline
\end{tabular}

Заметим, что самое общее по значению из финских водных звукоподражаний - это слово loisk, которое употребляется в самых разных водных ситуациях. Слово pläts также имеет широкий диапазон употреблений, но для него, в отличие от loisk, обязательно присутствие контакта воды с предметом. Комментарии респондентов дают повод полагать, что намеренность действия является дополнительным фактором, влияющим на выбор конкретного финского слова.

\section{Заключение}

Работа состояла в семантическом описании русских и финских водных звукоподражательных междометий. Разработанная на основе словарных материалов типология русских слов послужила основой для электронного анкетирования, проведенного среди 124 носителей финского языка для уточнения семантических признаков аналогичных финских слов, которые пока не описаны в словарях и которых почти нет в электронных корпусах финского языка.

Словари не только описывают значения слов, но и влияют на них. Более того, важным источником для составителей словарей являются другие словари. Используя качественные толковые словари, носитель языка подтверждает собственную языковую интуицию, а если данные словари противоречат его интуиции, он склонен полагать, что словарь прав. В случае русского языка новые словари могли бы в вопросе звукоподражательных междометий опираться и на данные электронных корпусов. Для финского языка дела обстоят совершенно иначе, потому что такие слова редко используются в кодифицированном языке, что связано с различиями в их синтаксических функциях. В разговорной речи эти слова, тем не менее, широко употребляются. Подобный метод семантического анализа может быть применен для малоописанных слов и в других славянских и неславянских языках.

\section{Литература}

1. Rhodes R. Aural images // Sound symbolism / eds. L. Hinton, J. Nichols, J.J. Ohala, Cambridge, 1994. P. 276-292.

2. Русская грамматика / гл. ред. Н.Ю. Шведова. М., 1980. Т. 1.783 с. 
3. Кор Шаин И. 'Плюх! - плюх - плюхнуть(ся): К вопросу об эволюции нарративных предикатов в свете корпусных данных // Инструментарий русистики: корпусные подходы / под ред. А. Мустайоки, М.В. Копотева, Л.А. Бирюлина, Е.Ю. Протасовой. Хельсинки, 2008. С. 152-162.

4. Зализняк А.А. Грамматический словарь русского языка: Словоизменение. М., 1980. $879 \mathrm{c}$.

5. Nikitina T. Russian verboids: a case study in expressive vocabulary // Linguistics. 2012. № 50/2. P. 165-189.

6. Середа Е.В. Морфология современного русского языка. Место междометий в системе частей речи. М., 2013. 159 с.

7. Schürmann M. 'Multimodal interactions: tactile-auditory' // Encyclopedia of Perception / ed. by E.B. Goldstein. Thousand Oaks, 2010. Vol. 1. P. 592-593.

8. Shams L. Multimodal interactions: visual-auditory // Encyclopedia of Perception / ed. by E.B. Goldstein. Thousand Oaks, 2010. Vol. 1. P. 595-597.

9. Spence C. Multimodal interactions: visual-haptic // Encyclopedia of Perception / ed. by E.B. Goldstein. Thousand Oaks, 2010. Vol. 1. P. 597-599.

10. Wallace, M. T. Multimodal integration: neural basis // Encyclopedia of Perception / ed. by E.B. Goldstein. Thousand Oaks, 2010. Vol. 1. P. 585-588.

11. Zellner D.A. Multimodal interactions: color-chemical // Encyclopedia of Perception / ed. by E.B. Goldstein. Thousand Oaks, 2010. Vol. 1. P. 584-585.

12. Mikone E. Deskriptiiviset sanat. Määritelmät, muoto ja merkitys. Helsinki, 2002. 156 p.

13. Jääskeläinen A. Todisteena äänen kuva. Helsinki, 2013. 361 p.

14. Виймаранта Й., Алекдандрова А.А, Богомолов А.С, Пасмор Е.С., Тикканен Л. «Водные» звукоподражания в финском и русском языках // Язык и культура. 2016. № 1 (33). P. 6-24.

15. Лурье С.Я. Неизменяемые слова в функции сказуемого в индоевропейских языках. Львов, 1955. $70 \mathrm{c.}$

16. Viimaranta J., Vihervä $M$. The use of onomatopoeic interjections in predicate function in Russian and other languages: A perspective from the Corpus of Parallel Texts of the Russian National Corpus // Scando-Slavica. 2019. № 65 : 2. P. 239-262.

17. Большой академический словарь русского языка : в 30 т. / ред. К.С. Горбачевич. СПб., 2004.

18. Ефремова T.Ф. Новый словарь русского языка: Толково-словообразовательный : в 2 т. М., 2000.

19. Большой толковый словарь русского языка / сост. и гл. ред. С.А. Кузнецов. СПб., 2000.

20. Haarala R. (ed.) Suomen kielen perussanakirja. Helsinki, 1990-1994.

21. Heinonen T.R. (ed.) Kielitoimiston sanakirja, version of 29.2.2016. URL: https://www.kielitoimistonsanakirja.fi/

22. Sadeniem, M. (ed.) Nykysuomen sanakirja. Juva, 1992.

Creating a Lexico-Semantic Typology of Water-Related Onomatopoeic Interjections (On Russian and Finnish Material)

Vestnik Tomskogo gosudarstvennogo universiteta. Filologiya - Tomsk State University Journal of Philology. 2020. 65. 5-29. DOI: 10.17223/19986645/65/1

Johanna Viimaranta, University of Helsinki (Helsinki, Finland). E-mail: johanna.viimaranta@helsinki.fi

Alexey S. Bogomolov, Åbo Akademi University (Turku, Finland). E-mail: bogomolov.alexey@mail.ru

Keywords: onomatopoeia, interjection, typology, Russian, Finnish.

This article is concerned with onomatopoeic interjections that describe the visual and acoustic effects produced when a subject or object comes into contact with water or another 
liquid. The aim of the research was to establish the criteria for devising a typology of such onomatopoeic expressions. The research material consisted of water-related onomatopoeic interjections in Russian and Finnish. While it is well known that such words can be used as predicates in Russian, descriptions of Finnish grammar make no reference to this type of syntactic function. Since words belonging to this group are recorded and codified in Russian dictionaries, but not in Finnish ones, the authors employed different methods for each of the two languages in examining the lexical material. After establishing a codified inventory of water-related onomatopoeic interjections in Russian, the authors analysed their dictionary meanings, which enabled them to reduce the semantic content of the interjections to a set of prototypical ideas. On the basis of this analysis, the authors created a typology of waterrelated situations and established the criteria for identifying onomatopoeic synonymy. To compensate for the absence of dictionary data for Finnish onomatopoeic interjections, native speakers were asked to fill in electronic questionnaires in which their task was to complete descriptive utterances, to make acceptability judgements concerning the use of particular onomatopoeic expressions, and to pinpoint the essential features of the situation described. The data obtained for both languages were systematized in tabular form in accordance with the typology of water-related onomatopoeic interjections presented in this article. In contemporary Russian, the codified inventory of water-related onomatopoeic interjection consists of the following words: bultykh, bul' or bul'k, kap, nyrk (nyr'), plyukh, pshik, khlest' (khles'), khlyup, chmok, and shlep. Words used in a similar way in contemporary Finnish include the following: kohi, kuoh, liri, liti, lits, loiskis, loti, läti, läts, molskis, pirsk, pläts, polskis, pori, pul(i), roiskis, and tip. It turned out that the major considerations influencing a speaker's choice of a suitable water-related onomatopoeic word include the following: (1) seriality: whether a sound (and, consequently, a word) is repeated; (2) the location at which the sound is produced, i.e. whether the object comes into contact with the surface of the liquid or with a deeper stratum; (3) the shape of the object that interacts with the liquid (flat or multidimensional); (4) the result of the interaction (whether or not complete immersion in the liquid takes place); and (5) the quality of the object's interaction with the liquid. Apart from comparisons between Finnish and Russian, this typology provides a framework for the contrastive analysis of water-related onomatopoeia in other languages as well.

\section{References}

1. Rhodes, R. (1994) Aural images. In: Hinton, L., Nichols, J. \& Ohala, J.J. (eds) Sound Symbolism. Cambridge: Cambridge University Press. pp. 276-292.

2. Shvedova, N.Yu. (ed.) (1980) Russkaya grammatika [Russian Grammar]. Vol. 1. Moscow: Nauka.

3. Kor Chaine, I. (2008) Plyukh! - plyukh - plyukhnut'(sya). K voprosu ob evolyutsii narrativnykh predikatov $\mathrm{v}$ svete korpusnykh dannykh [Plyukh! - plyukh - plyukhnut'(sya). To the question of the evolution of narrative predicates in relation to corpus data]. In: Mustajoki, A. et al. (eds) Instrumentariy rusistiki: korpusnye podkhody [Instrumentats of Russian Studies: Corpus approaches]. Helsinki: University of Helsinki. pp. 152-162.

4. Zaliznyak, A.A. (1980) Grammaticheskiy slovar' russkogo yazyka: Slovoizmenenie [Grammar Dictionary of the Russian Language: Inflection]. Moscow: Russkiy yazyk.

5. Nikitina, T. (2012) Russian verboids: a case study in expressive vocabulary. Linguistics. 50/2. pp. 165-189. DOI:10.1515/ling-2012-0007

6. Sereda, E.V. (2013) Morfologiya sovremennogo russkogo yazyka. Mesto mezhdometiy $v$ sisteme chastey rechi [Morphology of the Modern Russian Language. The place of interjections in the system of parts of speech]. Moscow: FLINTA.

7. Schürmann, M. (2010) Multimodal interactions: tactile-auditory. In: Goldstein, E.B. (ed.) Encyclopedia of Perception. Vol. I. Thousand Oaks, CA: Sage. pp. 592-593.

8. Shams, L. (2010) Multimodal interactions: visual-auditory. In: Goldstein, E.B. (ed.) Encyclopedia of Perception. Vol. I. Thousand Oaks, CA: Sage. pp. 595-597. 
9. Spence, C. (2010) Multimodal interactions: visual-haptic. In: Goldstein, E.B. (ed.) Encyclopedia of Perception. Vol. I. Thousand Oaks, CA: Sage. pp. 597-599.

10. Wallace, M.T. (2010) Multimodal integration: neural basis. In: Goldstein, E.B. (ed.) Encyclopedia of Perception. Vol. I. Thousand Oaks, CA: Sage. pp. 585-588.

11. Zellner, D.A. (2010) Multimodal interactions: color-chemical. In: Goldstein, E.B. (ed.) Encyclopedia of Perception. Vol. I. Thousand Oaks, CA: Sage. pp. 584-585.

12. Mikone, E. (2002) Deskriptiiviset sanat. Määritelmät, muoto ja merkitys. Helsinki: Suomalaisen Kirjallisuuden Seura.

13. Jääskeläinen, A. (2013) Todisteena äänen kuva. Helsinki: University of Helsinki.

14. Viimaranta, J. et al. (2016) Interjections pertaining to sounds of water in Finnish and Russian. Yazyk i kul'tura - Language and Culture. 1 (33). pp. 6-24. (In Russian). DOI: $10.17223 / 19996195 / 33 / 1$

15. Lur'e, S.Ya. (1955) Neizmenyaemye slova $v$ funktsii skazuemogo $v$ indoevropeyskikh yazykakh [Fixed Words with Predicate Function in Indo-European Languages]. Lviv: University of Lviv.

16. Viimaranta, J. \& Vihervä, M. (2019) The use of onomatopoeic interjections in predicate function in Russian and other languages: A perspective from the Corpus of Parallel Texts of the Russian National Corpus. Scando-Slavica. 65:2. pp. 239-262. DOI: 10.1080/00806765.2019.1672092

17. Gorbachevich, K.S. (ed.) (2004) Bol'shoy akademicheskiy slovar' russkogo yazyka [Large Academic Dictionary of the Russian Language]. Saint Petersburg: Nauka.

18. Efremova, T.F. (2000) Novyy slovar' russkogo yazyka. Tolkovo-slovoobrazovatel'nyy [New Dictionary of the Russian Language. Explanatory and derivational]. Moscow: Russkiy yazyk.

19. Kuznetsov, S.A. (2000) Bol'shoy tolkovyy slovar' russkogo yazyka [Large Explanatory Dictionary of the Russian Language]. Saint Petersburg: Norint.

20. Haarala, R. (ed.) (1990-1994) Suomen kielen perussanakirja. Helsinki: Valtion painatuskeskus.

21. Heinonen, T.R. (ed.) (2016) Kielitoimiston sanakirja. [Online] Available from: https://www.kielitoimistonsanakirja.fi/.

22. Sadeniem, M. (ed.) (1992) Nykysuomen sanakirja. Juva: Söderström. 